\title{
TECHNOLOGICAL CHARACTERIZATION OF LACTIC ACID BACTERIA ISOLATED FROM SHEEP MILK FOR POTENTIAL USE AS NON-STARTER CULTURES
}

\section{Caracterização tecnológica de bactérias ácido lácticas isoladas de leite de ovelha para uso potencial como culturas não-iniciadoras}

\author{
Maria Rita Souto Dias ${ }^{1}$, Andressa Fusieger², Amanda de Souza Motta*
}

\begin{abstract}
Sheep milk has different physicochemical properties, which means that its derived products have a high added value. Some of these properties are conferred by lactic bacteria which play important roles in the raw milk. This study aimed to analyze five lactic bacteria that were previously identified and evaluated for parameters such as their acidification, proteolysis, diacetyl and exopolysaccharides production, potential antimicrobial activity and safety parameters. The $16 \mathrm{~S}$ rDNA gene identification via sequencing showed an agreement with the data obtained by MALDI-TOF/MS. The bacteria were identified as Lactococcus lactis MRS1, Lactococcus lactis MRS2, Lactococcus lactis MRS5, Lactococcus lactis MRS6, and Enterococcus faecalis M173. All isolates showed the same acidification profile, maintaining a $\mathrm{pH}$ of 4.5 from $6 \mathrm{~h}$ of incubation, under the conditions employed. Proteolytic activity, coexistence capacity, and production of exopolysaccharides were observed in all the isolates tested. Diacetyl production was only evident in the isolates Lactococcus lactis MRS1 and Lactococcus lactis MRS2. Regarding the presence of antimicrobial activity, Lactococcus lactis MRS6 and Enterococcus faecalis M173 isolates inhibited all tested cultures. In the evaluation of the safety parameters, none of the isolates presented high-level resistance to clinically important antibiotics and did not present gelatinase production and hemolytic activity. These results provide important information on the potential bacteria that could become valuable additives in sheep milk-derived products, in a condition of starters or adjunct cultures.
\end{abstract}

Keywords: Lactococcus; Enterococcus; technological properties.

1 Golden Food Alimentos, Rio de Janeiro, RJ, Brasil.

2 Universidade Federal de Viçosa, Departamento de Tecnologia de Alimentos, Viçosa, MG, Brasil.

3 Universidade Federal do Rio Grande do Sul, Departamento Microbiologia, Imunologia e Parasitologia, Av. Paulo Gama, 110, Farroupilha, 90040-060, Porto Alegre, RS, Brasil. E-mail: amanda.motta@ufrgs.br

* Autor para correspondência 


\section{RESUMO}

O leite de ovelha possui diferentes propriedades físico-químicas, o que significa que seus derivados têm alto valor agregado. Parte dessas propriedades é conferida por bactérias lácticas que desempenham importantes atividades no leite cru. Esta pesquisa teve como objetivo analisar cinco bactérias lácticas previamente identificadas e avaliadas quanto a seus parâmetros de acidificação, proteólise, produção de diacetil e exopolissacarídeos, potencial atividade antimicrobiana e parâmetros de segurança. A identificação do gene 16S rDNA por sequenciamento mostrou concordância com os dados obtidos por MALDI-TOF/MS. As bactérias foram identificadas como Lactococcus lactis MRS1, Lactococcus lactis MRS2, Lactococcus lactis MRS5, Lactococcus lactis MRS6 e Enterococcus faecalis M173. Todos os isolados apresentaram o mesmo perfil de acidificação, mantendo o pH em 4,5 a partir de 6 horas de incubação, nas condições empregadas. Atividade proteolítica, capacidade de coexistência e produção de exopolissacarídeos foram observadas em todos os isolados testados. A produção de diacetil foi evidente nos isolados Lactococcus lactis MRS1 e Lactococcus lactis MRS2. Em relação à presença de atividade antimicrobiana, os isolados de Lactococcus lactis MRS6 e Enterococcus faecalis M173 inibiram todas as culturas testadas. Na avaliação dos parâmetros de segurança, nenhum dos isolados apresentou resistência de alto nível a antibióticos clinicamente importantes e não apresentaram produção de gelatinase e atividade hemolítica. Estes resultados fornecem uma informação importante sobre as potenciais bactérias a serem exploradas para a aplicação em produtos derivados de leite de ovelha, em condições de cultura starter ou adjuntas.

Palavras-chave: Lactococcus; Enterococcus; propriedades tecnológicas.

\section{INTRODUCTION}

At approximately 18 million head, Brazil is considered the eighteenth biggest sheep producer in the world (FAO, 2015). The dairy sheep industry is a young industry in Brazil, so its production and processing remain limited. It is estimated that the country processes around 509,000 liters of sheep milk per year, which corresponds to approximately 526 tons and only $0.0019 \%$ of the total milk processed in the country. Between 2004 and 2010, sheep milk production increased by $5.5 \%$ per year (ROHENKOHL, 2011). Compared to the composition information of cow milk, sheep milk stands out for its higher total of solid content, nutrients, dry extract, fat and proteins such as casein (MCKUSICK et al., 2002; BALTHAZAR et al., 2017).
These characteristics make it attractive for the elaboration of dairy products and justify its exceptional productivity in cheese making, as well as accentuated sensorial differences and coagulation properties (MCKUSICK et al., 2002; BARLOWSKA et al., 2011).

Despite the importance for the dairy industry, few studies have focused on autochthonous lactic microbiota in sheep milk. Most of the studies identified lactic acid bacteria (LAB) Enterococcus, Lactococcus, Lactobacillus and Leuconostoc as the most prevalent genera (CHANOS; WILLIAMS, 2011; IRANMANESH; EZZATPANAH, 2015). In general, the $\mathrm{LAB}$ constitute a heterogeneous group of Gram-positive bacteria, generally non-sporulating, characterized by bacilli or coccus morphology, catalase-negative, aerobic or facultatively anaerobic, acid-tolerant, and 
usually producing lactic acid as the major metabolic end-product of carbohydrate fermentation (CARR et al., 2002; LIU et al., 2011).

This group of bacteria has a high biotechnological potential in food production, especially in fermented dairy products due to their ability to produce desirable substances, that can be used for both a technological point of view as well as for food safety studies (LIU et al., 2011; GÄNZLE, 2015). In this context, this research aimed to identify and describe BAL from sheep milk and evaluate its technological properties, presenting new cultures with potential to enhance dairy sheep industry development.

\section{MATERIALS AND METHODS}

\section{Origin, identification and selection of lactic acid bacteria (LAB)}

Twenty-four bacteria previously isolated from sheep milk from Cabanha Dedo Verde (Viamão, RS, Brazil), belonging to the Microbiology Laboratory - ICBS/UFRGS collection, were studied. These bacteria were grown in Man Rogosa and Sharpe medium (MRS) (Oxoid Ltd., Basingstoke, England) as well as M17 (Oxoid) and stored in 20\% (v/v) glycerol at $-20{ }^{\circ} \mathrm{C}$. For the identification and selection as LAB, microorganisms were analyzed for their morphotinorial and biochemical properties through Gram staining and by the catalase test, respectively. Only cultures that presented Gram-positive and catalase negative, characteristics common to BAL, were selected.

\section{Identification of LAB by Matrix Associated Laser Desorption-Ionization - Time of Flight (MALDI-TOF/MS)}

The MALDI-TOF/MS was used to identify cultures selected by the parameters previously described (SAUGET et al.,
2016). Briefly, an MRS agar (Oxoid) culture was used, and a colony of each isolate was inoculated into $1.5 \mathrm{~mL}$ microtubes, with $300 \mu \mathrm{L}$ of Milli-Q water and $900 \mu \mathrm{L}$ of absolute ethanol. Subsequently, the samples were centrifuged at a speed of $\geq 13,000 \mathrm{rpm}$ for 2 min., the supernatant was discarded, and the pellet dried at room temperature. Then $70 \%$ formic acid $(30 \mu \mathrm{L})$ and pure acetonitrile $(30 \mu \mathrm{L})$ were added to the pellet, followed by vortex homogenization and a new centrifugation step for $2 \mathrm{~min}$. at a speed $\geq 13,000 \mathrm{rpm}$. All material was collected in a pellet. Then, $1 \mu \mathrm{L}$ of supernatant was pipetted onto a stainless-steel plate and dried at room temperature, followed by addition of $1 \mu \mathrm{L}$ of a matrix consisting of $\alpha$-cyano-4hydroxycinnamic acid solution (HCCA). The analyses were performed by MALDI-Biotyper (MBT OC) 4.0 software, at the Institute of Basic Health Sciences of the Federal University of Rio Grande do Sul.

\section{Identification of LAB by $16 \mathrm{~S}$ rDNA sequencing}

DNA extraction from selected isolates was carried out, and a polymerase chain reaction (PCR) amplification of $16 \mathrm{~S}$ rDNA was performed in an Applied Biosystems Thermal Cycler 2720 (Thermo Scientific, Madison, WI, USA) followed by sequencing bases. The PCR primers were FC 27 (5'-AGAGTTTGATCCTGGCTCAG-3') and R530 (5'-CCGCGGCTGCTGGCACGTA-3') (GONTANG et al., 2007). The reaction was carried out totalizing $25 \mu \mathrm{L}$, with $100 \mathrm{ng}$ of DNA, $1.5 \mathrm{mM}$ of magnesium chloride $\left(\mathrm{MgCl}_{2}\right.$, Quatro G, Pesquisa e Desenvolvimento, Porto Alegre, RS, Brazil), $0.4 \mu \mathrm{M}$ of each primer (Invitrogen, Life Technologies, Carlsbad, California, USA), 1 U Taq DNA polymerase (Quatro G), 1 X PCR buffer (Quatro G), $200 \mu \mathrm{M}$ dNTP (Ludwig Biotecnologia, Alvorada, RS, Brazil), and miliQ sterile water to complete the reaction volume. 
Cycling conditions consisted of an initial 5 min. denaturation step at $94{ }^{\circ} \mathrm{C}$, followed by 35 cycles of $1 \mathrm{~min}$ at $95{ }^{\circ} \mathrm{C}, 1 \mathrm{~min}$ at $58{ }^{\circ} \mathrm{C}, 1 \mathrm{~min}$ at $72{ }^{\circ} \mathrm{C}$, and a final $10 \mathrm{~min}$ extension step at $72{ }^{\circ} \mathrm{C}$. The sequencing of samples was performed at ACTGene Análises Moleculares (Biotechnology Center, UFRGS, Porto Alegre, RS, Brazil) using the ABI-Prism 3500 Genetic Analyzer (Applied Biosystems, Foster City, CA, USA). Sequencing data were collected using the Data Collection 2 program (Applied Biosystems). The results were analyzed by the Chromas software version 2.6.4 (Technelysium Pty Ltd South Brisbane, QLD, Australia) and compared to the database of the National Center for Biotechnology Information (NCBI) (https://www.ncbi.nlm. nih.gov/).

\section{Acidification capacity}

Aliquots $(1 \% \mathrm{v} / \mathrm{v})$ of revitalized strains were transferred to tubes containing MRS broth (Oxoid), whole and skimmed UHT milk (Nestlé, São Paulo, SP, Brazil), and incubated at $30^{\circ} \mathrm{C}$. The acidification capacity was determined by means of $\mathrm{pH}$ evaluation at time 0 and after $6,12,24$ and $48 \mathrm{~h}$ of incubation, using a pH test tape (RIBEIRO et al., 2014). Data were expressed as the mean of duplicate.

\section{Proteolytic activity}

Proteolytic activity was determined following the method of Franciosi et al. (2009). Two microliters of revitalized strains were spotted onto the surface of a Plate Count Agar (PCA, HiMedia, Mumbai, MH, India) composed of $10 \%$ of skim milk (w/v, Nestlé) and incubated at $30{ }^{\circ} \mathrm{C}$ for 4 days. As a positive control, the strain Pseudomonas aeruginosa ATCC 27853 was used and the experiment was carried out in triplicate. Proteolytic activity was indicated by a clear zone around the colonies.

\section{Diacetyl production}

For diacetyl production, revitalized strains $(1 \% \mathrm{v} / \mathrm{v})$ were inoculated in $10 \mathrm{~mL}$ of skim milk (10\% w/v, Nestlé) and incubated at $30{ }^{\circ} \mathrm{C}$ for $24 \mathrm{~h}$. Then, $1 \mathrm{~mL}$ of sample was combined with $0.5 \mathrm{~mL}$ of $\alpha$-naphthol $(1 \% \mathrm{w} / \mathrm{v}$, Merck Millipore, Darmstadt, HE, Germany) and potassium hydroxide $(\mathrm{KOH}, 16 \% \mathrm{w} / \mathrm{v}$, Grupo Química Industrial, Rio de Janeiro, RJ, Brazil) and incubated at $30{ }^{\circ} \mathrm{C}$ for $10 \mathrm{~min}$. The diacetyl production was indicated by the formation of a red ring at the top of the tubes (FRANCIOSI et al., 2009).

\section{Production of exopolysaccharides (EPS)}

The strains of LAB were tested for the production of EPS by the agar method with red congo (FREEMAN et al., 1989). Strains were plated by streaking and incubated at $37^{\circ} \mathrm{C}$ for $24 \mathrm{~h}$. As a positive control, the Staphylococcus epidermidis ATCC 35984 strain was used and the production of EPS was indicated by the black coloration of the colonies with a crystalline appearance.

\section{Coexistence among isolates of $\mathrm{LAB}$}

To analyze the coexistence capacity between the isolates, the bacteria were seeded on plates containing MRS agar (Oxoid). Each LAB isolate was individually seeded in a single line at the center and afterward, the other isolates were seeded perpendicularly at an angle of $90^{\circ}$ to the central isolate. The antagonism was verified through the formation of a zone of inhibition between the isolates and/or retraction in the bacterial growth (GUO et al., 2010).

\section{Evaluation of the production of anti- microbial activity by $L A B$}

The antimicrobial activity was per- 
formed according to the spot-on-the-lawn test (LEWUS et al., 1991), with modifications. Each BAL isolate was seeded in duplicate as a bite on plates containing MRS agar (Oxoid) and incubated at $30^{\circ} \mathrm{C}$ for $24 \mathrm{~h}$. The indicator microorganisms Escherichia coli ATCC 25922, Staphylococcus aureus ATCC 25923, Listeria monocytogenes ATCC 7644 and Pseudomonas aeruginosa ATCC 27853 were inoculated into Tryptone Soy Broth (TSB, Oxoid) and incubated at $37{ }^{\circ} \mathrm{C}$ for 24 h. Subsequently, plates were overcoated with an overlay of semi-solid TSB agar ( $0.6 \%$ agar, Oxoid) containing $1 \%(\mathrm{v} / \mathrm{v})$ of an indicator culture with a concentration of approximately $10^{5} \mathrm{CFU} / \mathrm{mL}$. The plates were incubated at $37^{\circ} \mathrm{C}$ for $24 \mathrm{~h}$ and the antimicrobial activity of the LAB against the indicator microorganisms was verified by the formation of inhibition halos around the bite of the LAB and measurement of the diameter in millimeters $(\mathrm{mm})$.

\section{Safety Parameters}

The susceptibility profile of LAB isolates was evaluated for the following antibiotics: amoxicillin + clavulanic acid, ampicillin, cephalexin, cefotaxime, chloramphenicol, erythromycin, streptomycin, gentamicin, rifampicin, tetracycline, and vancomycin. The BAL cell suspension was adjusted to the value of 0.5 of the McFarland scale and seeded with a sterile swab on plates containing Muller-Hinton Agar (Oxoid). Then, disks with each antimicrobial were placed on the surface of the plates and incubated at $37{ }^{\circ} \mathrm{C}$ for $48 \mathrm{~h}$. To evaluate the gelatinase production, the cultures were inoculated with a needle into tubes containing gelatin agar (Oxoid) and incubated at $37^{\circ} \mathrm{C}$ for $48 \mathrm{~h}$. The tubes were considered positive when the liquefaction of the medium was verified. As a positive control, the bacterium Pseudomonas aeruginosa ATCC 27853 was used. Hemolysis of erythrocytes was observed on Columbia agar (Oxoid) plates supplemented with 5\% sheep blood, where the bacterial suspensions were scored and incubated for $24 \mathrm{~h}$ at $37^{\circ} \mathrm{C}$. After this time, plaques were analyzed for hemolysis, and Staphylococcus aureus ATCC 25938 strain was used as a positive control.

\section{RESULTS AND DISCUSSION}

\section{Identification of lactic acid bacteria by mass spectrometry and 16S rDNA sequencing}

From the 24 isolates derived from sheep milk, five were characterized as LAB, Grampositive cocci and catalase negative. Relative to the identification by MALDI-TOF, it was used the predicted scores as parameters to infer the species or genera identification of the isolates previously selected by biochemical and morphological analysis. This methodology states that scores between 0.000 and 1.699 indicate an unreliable identification, between 1,700 and 1,999 as a probable identification of genera, scores between 2,000 and 2,299 as a safe identification at the genus level and a score between 2,300 and 3,000 indicates a reliable level for species identification. The analyzed bacteria presented the scores listed in Table 1.

Due to the score presented by M173 isolate (2.376), it can be inferred that its description at species level is reliable, allowing its identification as E. faecalis. The MRS1, MRS2, and MRS5 isolates presented safe scores at the genera level, all belonging to the Lactococcus genus and probably belonging to the lactis species. For the MRS6 isolate, the score obtained indicates a likely genus, possibly Lactococcus. Using MALDI-TOF/ MS methodology, García-Cayuela et al. (2017) identified L. lactis strains in samples of traditional cheeses made of raw goat and sheep milk. This reinforces the use of this technique as a notable tool for the identification of $L$. lactis species and subspecies. 
The identification of isolates by amplifying 16S rDNA (Table 1) confirmed the results at the genera and species levels obtained via MALDI-TOF/MS. Considering the results, the most frequent genus obtained were Lactococcus. Descriptions of L. lactis and E. faecalis in sheep milk have also been presented by Medina et al. (2001), Delavenne et al. (2012), Iranmanesh and Ezzatpanah (2015), and Kopčáková et al. (2018).

\section{Acidification capacity}

The strains were tested for acidification capacity in MRS broth, whole and skimmed UHT milk at $0,6,12,24$ and $48 \mathrm{~h}$. The results showed the same profile for all isolates, maintaining $\mathrm{pH}$ at 4.5 after $6 \mathrm{~h}$ of incubation. Rapid $\mathrm{pH}$ drop is very important during cheese production, contributing to changes in cheese texture and for the control of undesirable microorganisms. According to Beresford et al. (2001), the starter cultures should be capable of reducing milk pH to 5.3 or less after $6 \mathrm{~h}$ at 30-37 ${ }^{\circ} \mathrm{C}$. Studies have shown that most of the strains of BAL are initially slow in acid production (FRANCIOSI et al., 2009; MORANDI et al., 2011; DAL BELLO et al., 2012). However, in the present study, all isolates produced high levels of acidification after 6 h. Data presented by Perin et al. (2017) from isolates of raw goat milk, indicate a higher $\mathrm{pH}$ reduction in Lactococcus when compared to Enterococcus strains, showing high acidification profiles in milk after $6 \mathrm{~h}$ for Lactococcus and $24 \mathrm{hrs}$ for Enterococcus.

\section{Proteolytic activity, diacetyl and exopolysaccharides production}

The proteolytic activity was tested for all five isolates through observation of an opaque zone around the isolates in milk agar plates and variations in the diameter $(\mathrm{mm})$ of halos. The activity was observed in all isolates (Table 2). These results are in agreement with those reported by Tulini et al. (2016), in which strains of L. lactis were isolated from buffalo's milk and cheese with cow's milk and goat's milk, as well as strains of E. faecalis isolated from cow and buffalo's milk showed proteolytic characteristics. Perin et al. (2017) found proteolytic activity in E. faecalis and L. lactis strains, where a more proteolytic activity of E. faecalis was observed, due to the incidence of larger proteolytic halos when compared to L. lactis. Proteolytic activity is an essential property for starter cultures. The proteolytic system of LAB favors growth in milk to degrade caseins and peptides, aroma precursors and taste formation in the fermentation of dairy products and maturation of cheeses (TULINI et al., 2016).

The production of diacetyl was verified

Table 1 - The relation between bacterial isolates identified by MALDI-TOF/MS and 16S rDNA sequencing

\begin{tabular}{lcccc}
\hline & \multicolumn{2}{c}{ MALDI-TOF/MS } & \multicolumn{2}{c}{ 16S rDNA sequencing } \\
\cline { 2 - 5 } Isolate & Genera/species & Scores & Genera/species & $\begin{array}{c}\text { Identification } \\
\text { number }\end{array}$ \\
\hline MRS1 & Lactococcus lactis & 2.214 & Lactococcus lactis & MH681536 \\
MRS2 & Lactococcus lactis & 2.165 & Lactococcus lactis & MH681537 \\
MRS5 & Lactococcus lactis & 2.042 & Lactococcus lactis & MH681538 \\
MRS6 & Lactococcus lactis & 1.891 & Lactococcus lactis & MH681539 \\
M173 & Enterococcus faecalis & 2.376 & Enterococcus faecalis & MH681540 \\
\hline
\end{tabular}

a GenBank accession number for nucleotide sequence. 
Table 2 - Technological characteristics attributed to LABs isolated from sheep milk

\begin{tabular}{cccc}
\hline Isolate & Proteolytic activity $^{\mathrm{a}}$ & Diacetyl production $^{\mathrm{b}}$ & EPS production $^{\mathrm{b}}$ \\
\hline L. lactis MRS1 & 14,67 & + & + \\
L. lactis MRS2 & 16,34 & + & + \\
L. lactis MRS5 & 22,34 & - & + \\
L. lactis MRS6 & 21,00 & - & + \\
E. faecalis M173 & 16,34 & - & + \\
\hline
\end{tabular}

a halos diameter $(\mathrm{mm})$.

b $(+)$ positive result; $(-)$ negative result.

in the isolates L. lactis MRS1 and MRS2 (Table 2), with this characteristic commonly presented in L. lactis isolates (FRANCIOSI et al., 2009; DAL BELLO et al., 2012; DOMINGOS-LOPES et al., 2017; PERIN et al., 2017). The production of diacetyl is directly related to this type of strain. Since not all LABs have the capacity to metabolize the citrate, this behavior differs between species and subspecies. Diacetyl is a volatile compound generated as the final product in the conversion of citrate to pyruvate. It confers a buttery aroma to fermented dairy products and it is a common feature for LAB, such as L. lactis subsp. lactis biovar diacetylactis and some strains of Enterococcus (KEMPLER; MCKAY, 1981; SMIT et al., 2005; FRANCIOSI et al., 2009).

The production of EPS by LABs is an important characteristic for modifying the texture and viscosity of dairy products. In the present study, all the isolates presented black and crystalline colonies, indicating that they were positive for the EPS production (Table 2). Ribeiro et al. (2014) and Perin et al. (2017) did not verify the production of EPS for $L$. lactis and E. faecalis strains. Costa et al. (2010) found that the application of L. lactis strains producing EPS in Cheddar cheese resulted in a higher yield in the production, without negatively affecting the taste of the cheese. Also, favorable texture characteristics were attributed to the cheese, being described as soft, whereas cheeses in the absence of EPS were described as brittle. In this way, the generation of EPS is considered an important resource for LABs that are applied to dairy products, since soft and creamy products have considerable appeal to consumers. Therefore, this is a relevant feature in the selection of initial strains and secondary cultures (CAGGIANIELLO et al., 2016; LYNCH et al., 2018).

\section{Coexistence among isolates of $\mathrm{LAB}$}

The results demonstrated that all LAB isolates can coexist without interfering in the development of each other. This is an important feature, since it allows the application of different isolates in foods, providing distinct and desirable characteristics, enabling the improvement of a technological performance. Ribeiro et al. (2014) demonstrated that BALs from artisanal Pico cheese can coexist, but $L$. lactis inhibited the growth of all Enterococcus isolates. Observations by Leroy and De Vuyst (2004) suggest that the main application of $\mathrm{LAB}$ is as pure or mixed starter cultures. The production of fermented foods, especially dairy products, is based on the use of these cultures which initiate the rapid acidification of the raw material. They may also contribute to the flavor, texture and nutritional value of fermented foods and therefore can be used as adjunct cultures. 
Table 3 - Halos diameter $(\mathrm{mm})$ of LAB inhibition against indicator cultures. The data are present as means

\begin{tabular}{lcccc}
\hline Isolate & $\begin{array}{c}\text { E. coli } \\
\text { ATCC 25922 }\end{array}$ & $\begin{array}{c}\text { P. aeruginosa } \\
\text { ATCC 27853 }\end{array}$ & $\begin{array}{c}\text { L. monocytogenes } \\
\text { ATCC 7644 }\end{array}$ & $\begin{array}{c}\text { S. aureus } \\
\text { ATCC 25923 }\end{array}$ \\
\hline L. lactis MRS1 & 3.0 & 0 & 0 & 0 \\
L. lactis MRS2 & 8.5 & 0 & 0 & 10 \\
L. lactis MRS5 & 11.5 & 0 & 9 & 8 \\
L. lactis MRS6 & 21.5 & 20 & 11 & 12.5 \\
E. faecalis M173 & 26.5 & 21 & 10 & 9 \\
\hline
\end{tabular}

\section{Evaluation of the production of anti- microbial activity by LAB}

In the evaluation of the antimicrobial activity, L. lactis MRS6 and E. faecalis M173 showed activity in all tested indicator cultures (Table 3). All the L. lactis MRS1, MRS2 and MRS5 strains presented activity against E. coli ATCC 25922. Inhibition against L. monocytogenes ATCC 7644 was observed by L. lactis MRS5 strain, as well as, S. aureus ATCC 25923 inhibition by L. lactis MRS2 and MRS5. Variations in the halos diameters can be justified by the diversity and variety of antimicrobial substances that can be produced. These compounds can act by competitive exclusion and synthesis of antagonistic substances such as organic acids, hydrogen peroxide, carbon dioxide, diacetyl, acetaldehyde, and bacteriocins (GÁLVEZ et al., 2007; BALI et al., 2016).

These results demonstrate a potential application of the analyzed strains as bioprotective cultures. Inhibition of pathogenic bacteria by $\mathrm{LAB}$ is a positive feature since LAB starter cultures could confer an aspect of functionality, which contribute to a microbial safety or offer organoleptic, technological, nutritional, or health advantages (LEROY; DE VUYST, 2004; BINTSIS, 2018).

\section{Safety Parameters}

Regarding antibiotic susceptibility profile, the LAB isolates showed different sensibility to the antibiotics tested (Table 4). All isolates were sensitive to amoxicillin + clavulanic acid, ampicillin, cephalexin, cefotaxime, chloramphenicol, erythromycin, streptomycin and gentamicin. However, the L. lactis MRS1 and MRS2 isolates were resistant to rifampicin, and the $L$. lactis MRS5 and MRS6 isolates presented intermediate resistance to this antibiotic. Relative to tetracycline, L. lactis MRS1 and E. faecalis M173 isolates demonstrated intermediate resistance. This was also observed with L. lactis MRS5, however, relative to Vancomycin. Dal Bello et al. (2012) also found L. lactis isolates susceptible to chloramphenicol, gentamicin, rifampicin, and vancomycin. Domingos-Lopes et al. (2017) reported the resistance profile of enterococcal strains to chloramphenicol, cefotaxime, tetracycline, rifampicin, erythromycin, and chloramphenicol. In contrast, resistance to clinically important antibiotics, such as amoxicillin/clavulanic acid and vancomycin, has not been found.

These results point to antibiotic-resistance by LAB isolates of dairy origin, which can be attributed, in part, to the extensive use of these compounds in animal's 
Table 4 - Antibiotic susceptibility profile of LABs isolated from sheep milk. The data are presented as the mean of inhibition halos $(\mathrm{mm})$

\begin{tabular}{lccccccc}
\hline \multirow{2}{*}{ Antibiotic } & $\begin{array}{c}\text { L. lactis } \\
\text { MRS1 }\end{array}$ & $\begin{array}{c}\text { L. lactis } \\
\text { MRS2 }\end{array}$ & $\begin{array}{c}\text { L. lactis } \\
\text { MRS5 }\end{array}$ & $\begin{array}{c}\text { L. lactis } \\
\text { MRS6 }\end{array}$ & $\begin{array}{c}\text { E.faeca- } \\
\text { lis M173 }\end{array}$ & R $^{\mathrm{a}}$ & $\mathrm{S}^{\mathrm{b}}$ \\
\hline Amoxicillin + ac. Clavulanic & 62 & 42 & 42 & 38 & 61 & $\leq 13$ & $\geq 18$ \\
Ampicillin & 44 & 40 & 38 & 38 & 44 & $\leq 13$ & $\geq 17$ \\
Cephalexin & 44 & 36 & 34 & 38 & 30 & $\leq 14$ & $\geq 18$ \\
Cefotaxime & 56 & 40 & 38 & 43 & 44 & $\leq 22$ & $\geq 26$ \\
Chloramphenicol & 36 & 36 & 30 & 32 & 44 & $\leq 12$ & $\geq 18$ \\
Erythromycin & 40 & 40 & 35 & 38 & 38 & $\leq 13$ & $\geq 23$ \\
Streptomycin & 24 & 26 & 22 & 24 & 17 & $\leq 11$ & $\geq 15$ \\
Gentamicin & 30 & 35 & 33 & 32 & 26 & $\leq 12$ & $\geq 15$ \\
Rifampicin & 16 & 15 & 17 & 17 & 32 & $\leq 16$ & $\geq 20$ \\
Tetracycline & 18 & 40 & 49 & 31 & 18 & $\leq 14$ & $\geq 19$ \\
Vancomycin & 24 & 26 & 16 & 24 & 30 & $\leq 14$ & $\geq 17$ \\
\hline
\end{tabular}

a (R) resistant.

b (S) sensitive.

Source: SENSIFAR AND MULTIFAR-CEFAR $®, 2015$.

and human's care in recent years. Although resistance to antibiotics per se is not harmful, the spread of antibiotic resistant genes to other organisms is one of the most important safety issues. Concerning the use of bacteria in a variety of food products, the food chain is considered one of the main routes for the transmission of antibiotic-resistant bacteria (PESAVENTO et al., 2014; SHARMA et al., 2014). In general, due to food safety reasons, the absence of antibiotic-resistance in LAB is of great importance for its use as starter cultures or co-cultures (FRANCIOSI et al., 2009; SHARMA et al., 2014).

Regarding the results of hemolytic activity and gelatinase production, all LAB isolates showed negative results. Relative to hemolytic activity, Ribeiro et al. (2014) also found negative results in L. lactis and E. faecalis isolates. The inability to produce gelatinase is gratifying since gelatinase is a proteolytic enzyme mainly associated with Enterococcus and may be related to virulence profile. The degradation of the host tissue by the bacteria may provide nutrients for their survival and also contribute to the formation of biofilm (FRANZ et al., 2011).

\section{CONCLUSIONS}

The technological characterization of $L$. lactis and E. faecalis isolates from sheep milk showed a favorable potential to using them in the industry as a starter culture. A variability of technologically relevant characteristics was found among the isolates and may be the basis for the selection of specific strains to be used as starter or adjunct cultures. Selected isolates with acidifying ability, proteolytic activity, diacetyl and exopolysaccharides production have the potential to be used as adjuvant cultures in the manufacture of cheeses. In addition, the cultures meet safety criteria, since no isolates presented high resistance to clinically important antibiotics and did not present gelatinase production and hemolytic activity. Technological characteristics associated with LABs isolated from sheep milk are little reported in the literature, which highlights the importance of the present study, 
showing that these isolates are promising candidates for application as adjuvant cultures in cheese production.

\section{REFERENCES}

BALI, V. et al. Bacteriocins: Recent Trends and Potential Applications. Critical Reviews in Food Science and Nutrition, v. 56, n. 5, p. 817-834, 2016.

BALTHAZAR, C. F. et al. Sheep Milk: Physicochemical Characteristics and Relevance for Functional Food Development. Comprehensive Reviews in Food Science and Food Safety, v. 16, n. 2, p. 247-262, 2017.

BARLOWSKA, J. et al. Nutritional Value and Technological Suitability of Milk from Various Animal Species Used for Dairy Production. Comprehensive Reviews in Food Science and Food Safety, v. 10, n. 6, p. 291-302, 2011.

BERESFORD, T. P. et al. Recent Advance in Cheese Microbiology. International Dairy Journal, v. 11, p. 259-274, 2001.

BINTSIS, T. Lactic acid bacteria: their applications in foods. Journal of Bacteriology \& Mycology, v. 6, n. 2, p. 89-94, 2018. z. 4, p. 281-370, 2002.

CAGGIANIELLO, G.; KLEEREBEZEM, M.; SPANO, G. Exopolysaccharides produced by lactic acid bacteria: from health-promoting benefits to stress tolerance mechanisms. Applied Microbiology and Biotechnology, v. 100, n. 9, p. 3877-3886, 2016.

CARR, F. J.; CHILL, D.; MAIDA, N. The lactic acid bacteria: A literature survey. Critical Reviews in Microbiology, v. 28, n. 4, p. 281-370, 2002.

CHANOS, P.; WILliams, D. R. Anti-
Listeria bacteriocin-producing bacteria from raw ewe's milk in northern Greece. Journal of Applied Microbiology, v. 110, p. 757768, 2011.

COSTA, N. E. et al. Effect of exopolysaccharide produced by isogenic strains of Lactococcus lactis on half-fat Cheddar cheese. Journal of Dairy Science, v. 93, n. 8, p. 3469-3486, 2010 .

DAL BELLO, B. et al. Technological characterization of bacteriocin producing Lactococcus lactis strains employed to control Listeria monocytogenes in Cottage cheese. International Journal of Food Microbiology, v. 153, n. 1-2, p. 58-65, 2012.

DELAVENNE, E. et al. Biodiversity of antifungal lactic acid bacteria isolated from raw milk samples from cow, ewe and goat over one-year period. International Journal of Food Microbiology, v. 155, n. 3, p. 185190, 2012.

DOMINGOS-LOPES, M. F. P. et al. Genetic diversity, safety and technological characterization of lactic acid bacteria isolated from artisanal Pico cheese. Food Microbiology, v. 63, p. 178-190, 2017.

FAO. FAO Statistical Pocketbook. Rome, 2015.

FRANCIOSI, E. et al. Biodiversity and technological potential of wild lactic acid bacteria from raw cows' milk. International Dairy Journal, v. 19, n. 1, p. 3-11, 2009.

FRANZ, C. M. A. P. et al. Enterococci as probiotics and their implications in food safety. International Journal of Food Microbiology, v. 151, n. 2, p. 125-140, 2011.

FREEMAN, D. J.; FALKINER, F. R.; PATRICK, S. New method for detecting 
slime production by coagulase negative staphylococci. Journal of Clinical Pathology, v. 42, p. 872-874, 1989.

GÁLVEZ, A. et al. Bacteriocin-based strategies for food biopreservation. International Journal of Food Microbiology, v. 120, p. 51-70, 2007.

GÄNZLE, M. G. Lactic metabolism revisited: Metabolism of lactic acid bacteria in food fermentations and food spoilage. Current Opinion in Food Science, v. 2, p. 106-117, 2015.

GARCÍA-CAYUELA, T. et al. Rapid detection of Lactococcus lactis isolates producing the lantibiotics nisin, lacticin 481 and lacticin 3147 using MALDI-TOF MS. Journal of Microbiological Methods, v. 139, p. 138142, 2017.

GONTANG, E. A.; FENICAL, W.; JENSEN, P. R. Phylogenetic diversity of gram-positive bacteria cultured from marine sediments. Applied and Environmental Microbiology, v. 73, n. 10, p. 3272-3282, 2007.

GUO, X. H. et al. Screening lactic acid bacteria from swine origins for multistrain probiotics based on in vitro functional properties. Anaerobe, v. 16, n. 4, p. 321-326, 2010.

IRANMANESH, M.; EZZATPANAH, H. Characterization and Kinetics of Growth of Bacteriocin like Substance Produced by Lactic Acid Bacteria Isolated from Ewe Milk and Traditional Sour Buttermilk in Iran. Journal of Food Processing \& Technology, v. 6 , n. 12, 2015.

KEMPLER, G. M.; MCKAY, L. L. Biochemistry and Genetics of Citrate Utilization in Streptococcus lactis ssp. diacetylactis1. Journal of Dairy Science, v. 64, n. 7, p. $1527-1539,1981$.

KOPČÁKOVÁ, A. et al. Restrictionmodification systems and phage resistance of enterococci from ewe milk. LWT - Food Science and Technology, v. 93, p. 131-134, 2018.

LEROY, F.; DE VUYST, L. Lactic acid bacteria as functional starter cultures for the food fermentation industry. Trends in Food Science and Technology, v. 15, n. 2, p. 6778, 2004.

LEWUS, C. B.; KAISER, A.; MONTVILLE, T. J. Inhibition of Food-Borne Bacterial Pathogens by Bacteriocins from Lactic Acid Bacteria Isolated from Meatt. Applied and Environmental Microbiology, v. 57, n. 6, p. 1683-1688, 1991.

LIU, S.; HAN, Y.; JIANG ZHOU, Z. Lactic acid bacteria in traditional fermented Chinese foods. Food Research International, v. 44, n. 3, p. 643-651, 2011.

LYNCH, K. M. et al. Lactic Acid Bacteria Exopolysaccharides in Foods and Beverages: Isolation, Properties, Characterization, and Health Benefits. Annual Review of Food Science and Technology, v. 9, n. 1, p. 155176, 2018.

MCKUSICK, B. C. et al. Effect of Milking Interval on Alveolar Versus Cisternal Milk Accumulation and Milk Production and Composition in Dairy Ewes. Journal of Dairy Science, v. 85, n. 9, p. 2197-2206, 2002.

MEDINA, R. et al. Characterization of the Lactic Acid Bacteria in Ewe's Milk and Cheese from Northwest Argentina. Journal of Food Protection, v. 64, n. 4, p. 559-563, 2001. 
MORANDI, S.; BRASCA, M.; LODI, R. Technological, phenotypic and genotypic characterisation of wild lactic acid bacteria involved in the production of Bitto PDO Italian cheese. Dairy Science and Technology, v. 91, n. 3, p. 341-359, 2011.

PERIN, L. M. et al. Technological Properties and Biogenic Amines Production by Bacteriocinogenic Lactococci and Enterococci Strains Isolated from Raw Goat's Milk. Journal of Food Protection, v. 80, n. 1, p. 151-157, 2017.

PESAVENTO, G. et al. Prevalence and antibiotic resistance of Enterococcus spp. isolated from retail cheese, ready-to-eat salads, ham, and raw meat. Food Microbiology, v. 41, p. 1-7, 2014.

RIBEIRO, S. C. et al. Technological properties of bacteriocin-producing lactic acid bacteria isolated from Pico cheese an artisanal cow's milk cheese. Journal of Applied Microbiology, v. 116, n. 3, p. 573-585, 2014.

ROHENKOHL, J. E. O agronegócio agronegócio de leite de ovinos e caprinos
Características do segmento no mundo. Indicadores Econômicos FEE, p. 97-114, 2011.

SAUGET, M. et al. Matrix-assisted laser desorption ionization-time of flight Mass spectrometry can detect Staphylococcus aureus clonal complex 398. Journal of Microbiological Methods, v. 127, p. 20-23, 2016.

SHARMA, P. et al. Antibiotic resistance among commercially available probiotics. Food Research International, v. 57, p. 176195, 2014.

SMIT, G.; SMIT, B. A.; ENGELS, W. J. M. Flavour formation by lactic acid bacteria and biochemical flavour profiling of cheese products. FEMS Microbiology Reviews, v. 29, n. 3, p. 591-610, 2005.

TULINI, F. L. et al. Screening for antimicrobial and proteolytic activities of lactic acid bacteria isolated from cow, buffalo and goat milk and cheeses marketed in the southeast region of Brazil. Journal of Dairy Research, v. 83, n. 01, p. 115-124, 2016. 